\title{
PENGEMBANGAN MEDIA KARTU KATA UNTUK MELATIH KETERAMPILAN MEMBACA PERMULAAN PADA SISWA KELAS 1 SD
}

\author{
Rumidjan \\ Sumanto \\ A.Badawi \\ Program Studi PGSD Jurusan KSDP FIP Universitas Nergeri Malang \\ Jln. Semarang 5 Malang. \\ Email: rumidjan@gmail.com.id
}

\begin{abstract}
This study aims at developing a media card for basic reading skill on first graders of elementarys chool. To achieve this goal, this research used qualitative research approach. Based on the results of small group trials the following data are obtained regarding the media: (1) $100 \%$ enjoyable, (2) $100 \%$ secure, (3) $100 \%$ easy, and (4) $96,87 \%$ appropriate language use. In accordance with the large group trials, the following data are obtained (1) $94 \%$ enjoyable (2) $100 \%$ secure (3) $94 \%$ easy-to-use (4) 97,18\% appropriate language use. Based on the data that has been obtained above, word card media can be used without revision as an alternative learning in Indonesian language learning to practice the skills basic reading on first graders of elementary school.
\end{abstract}

Keywords: development, media word cards, basic reading, elementary school

\begin{abstract}
Abstrak: Penelitian ini bertujuan mengembangkan media kartu kata untuk membaca permulaan kelas 1 SD. Untuk mencapai tujuan tersebut penelitian ini menggunakan pendekatan penelitian kualitatif. Berdasarkan hasil uji coba kelompok kecil diperoleh data sebagai berikut (1) Kesenangan 100\%, (2) Keamanan 100\%, (3) Kemudahan 100\%, (4) Aspek bahasa 96,87\%. Berdasarkan uji coba kelompok besar diperoleh data sebagai berikut (1) Kesenangan 94\% (2) Keamanan 100\%(3) Kemudahan 94\% (4) Aspek bahasa 97,18\%. Berdasarkan data yang telah diperoleh di atas maka produk media kartu kata ini dapat digunakan tanpa revisi sebagai salah satu alternatif pembelajaran pembelajaran bahasa Indonesia untuk melatih keterampilan membaca permulaan pada siswa kelas $1 \mathrm{SD}$.
\end{abstract}

Kata kunci: pengembangan, media kartu kata, membaca permulaan, SD

Pendidikan di Sekolah Dasar (SD) bertujuan agar siswa memiliki pengetahuan dasar yang sangat berguna bagi kelanjutan studi serta dalam kehidupan di masyarakat (Depdiknas, 2006). Oleh karena itu, perlu pemahaman konsep yang sesuai sehingga pengetahuan yang diperoleh siswa dapat selalu diingat dengan baik. Agar terwujud tujuan tersebut, maka ditetapkan beberapa mata pelajaran yang harus dipelajari di SD salah satunya mata pelajaran Bahasa Indonesia.

Menurut Tarigan (1983:1) keterampilan berbahasa mencakup 4 aspek yaittu mendengarkan, berbicara, membaca, dan menulis. Dalam prosesnya belajar bahasa adalah belajar berkomunikasi, oleh karena itu pembelajaran bahasa

Indonesia diarahkan untuk meningkatkan kemampuan siswa dalam berkomunikasi dengan 
bahasa Indonesia baik lisan maupun tulisan. Pembelajaran bahasa selain untuk meningkatkan kemampuan berpikir, bernalar, dan kemampuan memperluas wawasan. Sejalan dengan hal tersebut, siswa diharapkan mampu memahami informasi yang disampaikan secara langsung atau tidak langsung (Santosa, dkk., 2007)

Membaca merupakan salah satu kemampuan dasar yang harus dimiliki oleh setiap siswa selain menulis dan berhitung. Keterampilan membaca menjadi dasar utama dalam belajar, dengan membaca siswa akan memperoleh pengetahuan yang bermanfaat bagi pertumbuhan dan perkembangan daya nalar, sosial dan emosionalnya. Ada empat profil pembelajaran membaca di sekolah dasar yaitu: (1) menyimak sambil mambaca, dijelaskan isinya, menjawab soal, dan menceritakan isinya, (2) membaca judul, bergantian membacakan teks, mencari isi paragraph, menjawab pertanyaan, dan bergantian membacakan teks, (3) membaca keras bersama-sama, dijelaskan isinya, permainan kata, mencari pokok pikiran, mengerjakan latihan, dan mengarang berdasarkan gambar, dan (4) membaca dalam hati, berlatih bercerita, bercerita di depan kelas, dan menuliskan kembali isi cerita (Basuki, 2011). Mengingat peranan membaca sangat penting bagi perkembangan siswa maka keterampilan membaca harus diajarkan sejak dini.

Membaca merupakan salah satu jenis kemampuan berbahasa yang bersifat reseptif. Disebut reseptif karena dengan membaca seseorang akan dapat memperoleh informasi, memperoleh ilmu pengetahuan, serta pengalaman-pengalaman baru. Semua yang diperoleh melalui bacaan itu memungkinkan orang tersebut mampu mempertinggi daya pikirnya, mempertajam pandangan, dan memperluas wawasannya. Hal ini, dapat dikaji tentang kemampuan literasi pelajar Indonesia pernah dipublikasikan oleh PISA (2003) yang menyimpulkan rendahnya kemampuan literasi pelajar Indonesia yang berumur 15 tahun. Menurut PISA (2003), prestasi literasi pelajar Indonesia menduduki peringkat ke-39 dari 42 negara yang dijadikan sampel penelitian (Hartati, 2016). Dengan demikian maka kegiatan membaca merupakan kegiatan sangat diperlukan oleh siapapun yang ingin maju dan meningkatkan diri. Oleh sebab itu, pembelajaran membaca di sekolah mempunyai peranan penting (Zuchdi \& Budiasih, 1997:49). Hasil observasi di lapangan dan informasi dari guru kelas 1 SD pada tanggal 16 September
2015 mengungkapkan, bahwa siswa kelas 1 yang berjumlah 31 siswa, sebanyak 6 siswa keterampilan membaca masih rendah. Hal tersebut dikarenakan oleh beberapa faktor, yaitu (1) siswa kurang aktif dalam kegiatan pembelajaran, hal ini disebabkan karena siswa kurang siap menerima pembelajaran, kurangnya interaksi dengan guru, (2) pemilihan dan penggunaan strategi, pendekatan serta metode pembelajaran yang dilaksanakan oleh guru kurang sesuai serta guru tidak menggunakan media alat peraga sehingga siswa cenderung terasa membosankan dan kurang termotivasi.

Berdasarkan observasi tersebut maka peneliti ingin membuat pembelajaran berbeda dengan sebelumnya yaitu menggunakan media kartu kata. Media Kartu kata ini bertujuan agar siswa lebih tertarik untuk membaca, karena dalam media kartu kata ini tersedia beberapa macam warna untuk menarik perhatian siswa. Selain itu media kartu kata ini sesuai dengan pembelajaran membaca permulaan (Setyoningsih, 2008).

Penggunaan media pembelajaran bukan saja dapat mempermudah dan mengefektifkan proses pembelajaran, akan tetapi juga bisa membuat proses pembelajaran lebih menarik (Sanjaya, 2009:162). Media kartu kata yang dibuat oleh peneliti dapat meningkatkan semangat belajar siswa. Karena dalam pembelajarannya dilakukan dengan bermain. Sehingga siswa dapat belajar sambil bermain.

\section{METODE}

Penelitian ini dirancang dengan menggunakan penelitian pengembangan dengan proses evaluatif melalui pendekatan kualitatif dan kuantitatif. Dalam penelitian ini penulis menggunakan metode evaluatif untuk mengevaluasi proses uji coba pengembangan suatu produk. Produk dikembangkan melalui serangkaian uji coba, dan setiap kegiatan uji coba diadakan evaluasi, baik evaluasi hasil maupun evaluasi proses. Berdasarkan temuan-temuan hasil uji coba diadakan penyempurnaan-penyempurnaan (Sukmadinata, 2009: 167).

Instrumen teknik pengumpulan data yang digunakan dalam pengembangan media kartu kata ini adalah dengan pendekatan kualitatif dan kuantitatif yang berupa wawancara, observasi, dan kuesioner.

Teknik analisis data yang digunakan dalam penelitian ini dan evaluasi para ahli untuk uji coba produk adalah data kualitatif dan kuantitatif 
berupa persentase. Data kualitatif ini diperoleh dari ahli pembelajaran anak usia dini, ahli bahasa, ahli permainan, dan pengguna (guru) yang berupa saran dan masukan yang digunakan untuk melakukan revisi terhadap rancangan produk. Sedangkan data kuantitatif berupa presentase kemudahan, keamanan, dan kesenangan serta keberhasilan siswa pada aspek bahasa saat melakukan pembelajaran menggunakan media kartu kata.

\section{HASIL}

\section{Validasi dari Ahli dan Pengguna}

Berdasarkan hasil evaluasi yang diperoleh dari ahli media pembelajaran mengenai rancangan produk yang dikembangkan, yaitu dari 34 aspek penilaian terkait dengan produk media yang terlampir menyatakan tingkat kelayakannya $80,59 \%$. Berdasarkan hasil klasifikasi persentase yaitu 75,01\%$100 \%$ tergolong dalam klasifikasi sangat valid maka dapat dinyatakan baik dan layak dengan mengikuti saran-saran yang telah dikemukakan. Adapun saran dan masukan ahli media pembelajaran yaitu gambar ilustrasi yang berupa bentuk komik sebaiknya diganti dengan gambar natural yang diambil dari internet.

Berdasarkan hasil evaluasi yang diperoleh dari ahli materi mengenai rancangan produk yang dikembangkan, yaitu dari 34 aspek penilaian terkait dengan pembelajaran siswa menyatakan $84,55 \%$. Berdasarkan hasil klasifikasi persentase yaitu $75,01 \%-100 \%$ tergolong dalam klasifikasi sangat valid maka dapat dinyatakan baik dan layak dengan mengikuti saran-saran yang telah dikemukakan. Adapun saran dan masukkan dari ahli materi adalah contoh penulisan huruf tegak bersambung perlu ditampilkan. Berdasarkan hasil evaluasi yang diperoleh dari ahli pengguna (guru) mengenai rancangan produk yang dikembangkan, yaitu dari 13 aspek penilaian terkait dengan pembelajaran siswa pada tabel terlampir menyatakan $92,30 \%$. Hal ini, guru harus kreatif dalam mengupayakan keaktifan siswa dengan cara berikut ini. Pertama, menggunakan model-model peran. Kedua, menggunakan profil orang kreatif. Ketiga, mendorong kolaborasi kreatif. Keempat, mengimajinasikan sudut pandang orang lain (Irtaji, 2014).

Berdasarkan hasil klasifikasi persentase yaitu $75,01 \%-100 \%$ tergolong dalam klasifikasi sangat valid maka dapat dinyatakan baik dan layak dengan mengikuti saran-saran yang telah dikemukakan. Adapun saran dan masukan dari ahli pengguna adalah penampilan dan persiapan mengajar sudah cukup bagus, namun tolong dihindari pemenggalan kata dan siswa yang meneruskan. Contohnya: anak-anak harus selalu melaksanakan kewa- siswa meneruskan -jiban.

\section{Uji Kelompok Kecil}

Hasil uji coba kelompok kecil terhadap produk awal media kartu kata untuk melatih keterampilan membaca permulaan pada siswa kelas 1 SDN. Dalam pembelajaran membaca permulaan diperoleh dari observasi tentang kemudahan, kesenangan, dan kemampuan siswa dalam pengaplikasian kegiatan pembelajaran menggunakan media kartu kata serta keberhasilan siswa pada aspek keterampilan membaca permulaan yang dilakukan oleh satu orang guru kelas 1.

Berdasarkan hasil analisis uji coba kelompok kecil terhadap 8 siswa kelas 1 SDN Kemantren 01 Kecamatan Jabung Kabupaten Malang, dengan kemudahan pelaksanaan pembelajaran menggunakan media kartu kata diperoleh data hasil uji coba pada tabel terlampir sebanyak $100 \%$ siswa mudah melakukan pembelajaran menggunakan media kartu kata. Dengan demikian hasil klasifikasi persentase yaitu 75,01\% - $100 \%$ tergolong dalam klasifikasi sangat valid (dapat digunakan tanpa revisi). Dari penilaian tersebut dapat disimpulkan bahwa media kartu kata mudah dilakukan pada pembelajaran membaca permulaan siswa kelas 1 SD.

Hasil uji coba kelompok kecil juga dilakukan terhadap 8 siswa yang diambil dari 2 kelompok, dan tiap-tiap kelompok terdiri dari 4 siswa. Pengisian data pada siswa dilakukan oleh satu orang guru kelas 1 dengan menanyakan secara langsung pada siswa tentang kesenangan siswa dalam pembelajaran menggunakan media kartu kata.

Berdasarkan hasil analisis uji coba kelompok kecil terhadap 8 siswa kelas 1 terkait dengan kesenangan siswa pada pembelajaran menggunakan media kartu kata diperoleh data hasil uji coba, sebanyak $100 \%$ siswa senang melakukan pembelajaran menggunakan media kartu kata. Dengan demikian hasil klasifikasi persentase yaitu antara $75,01 \%-100 \%$ tergolong dalam klasifikasi sangat valid (dapat digunakan tanpa revisi). Dari penilaian tersebut dapat disimpulkan bahwa pembelajaran 
menggunakan media kartu kata menyenangkan untuk diterapkan di siswa kelas 1 SD.

Hasil uji coba kelompok kecil juga dilakukan terhadap 8 siswa yang diambil dari 2 kelompok, dan tiap-tiap kelompok terdiri dari 4 siswa. Pengisian data pada siswa dilakukan oleh satu orang guru kelas 1 dengan melakukan observasi pada siswa tentang keamanan siswa dalam melakukan pembelajaran menggunakan media kartu kata. Data hasil uji coba kelompok kecil tentang keamanan siswa terhadap pembelajaran menggunakan media kartu kata.

Berdasarkan hasil analisis uji coba kelompok kecil terhadap 8 siswa kelas 1 SDN Kemantren 01 terkait dengan keamanan siswa pada pembelajaran menggunakan media kartu kata diperoleh data hasil uji coba sebanyak $100 \%$ siswa aman melakukan aktivitas pembelajaran menggunakan media kartu kata. Dengan menggunakan media pembelajaran bukan saja dapat mempermudah dan mengefektifkan proses pembelajaran, akan tetapi juga bisa membuat proses pembelajaran lebih menarik Sanjaya (2009:162). Dengan demikian hasil klasifikasi persentase yaitu antara $75,01 \%-100 \%$ tergolong dalam klasifikasi sangat layak (dapat digunakan tanpa revisi). Dari penilaian tersebut, disimpulkan bahwa media kartu kata aman untuk pembelajaran di kelas $1 \mathrm{SD}$.

Hasil uji coba kelompok kecil juga dilakukan terhadap 8 siswa yang diambil dari 2 kelompok, dan tiap-tiap kelompok terdiri dari 4 siswa. Pengisian data pada siswa dilakukan oleh satu orang guru kelas 1 dengan menanyakan secara langsung pada siswa tentang kesenangan siswa dalam melakukan pembelajaran menggunakan media kartu kata.

Berdasarkan hasil analisis uji coba kelompok kecil terhadap 8 siswa SDN Kemantren 01 terkait dengan kesenangan siswa pada media kartu kata diperoleh data hasil uji coba sebanyak $100 \%$ siswa senang melakukan pembelajaran menggunakan media kartu kata. Agar lebih tertarik dan senang pengembangan dengan model CD interaktif untuk pembelajaran membaca permulaan pada kelas 1 SD (Sukartiningsih, 2010). Dengan demikian hasil klasifikasi persentase yaitu antara 75,01\% - 100\% tergolong dalam klasifikasi sangat layak (dapat digunakan tanpa revisi). Dari penilaian tersebut dapat disimpulkan bahwa media kartu kata menyenangkan untuk pembelajaran membaca permulaan di kelas $1 \mathrm{SD}$.

Hasil uji coba kelompok kecil juga dilakukan terhadap 8 siswa yang diambil dari 2 kelompok, dan tiap-tiap kelompok terdiri dari 4 siswa. Pengisian data pada siswa dilakukan oleh satu orang guru kelas 1 dengan melakukan observasi pada siswa tentang kemudahan siswa dalam pembelajaran menggunakan media kartu kata.

Berdasarkan hasil analisis uji coba kelompok kecil terhadap 8 siswa kelas 1 SDN Kemantren 01 terkait dengan kemudahan siswa menggunakan media kartu kata diperoleh data hasil uji coba sebanyak $100 \%$ siswa mudah dalam menggunakan media kartu kata. Dengan demikian hasil klasifikasi persentase yaitu antara $75,01 \%-100 \%$ tergolong dalam klasifikasi sangat layak (dapat digunakan tanpa revisi). Dari penilaian tersebut dapat disimpulkan bahwa media kartu kata mudah untuk pembelajaran membaca permulaan di kelas 1 SD.

Hasil uji coba kelompok kecil juga dilakukan terhadap 8 siswa yang diambil dari 2 kelompok , dan tiap-tiap kelompok terdiri dari 4 siswa. Pengisian data pada siswa dilakukan oleh satu orang guru kelas 1 dengan melakukan observasi pada siswa terkait dengan keberhasilan siswa pada aspek perkemabangan bahasa dalam menggunakan media kartu kata. Data hasil uji coba kelompok kecil tentang keberhasilan siswa menggunakan media kartu kata pada aspek bahasa.

Hasil pengolahan data hasil uji coba kelompok kecil terkait dengan keberhasilan siswa pada aspek perkembangan bahasa yaitu mencapai $96,87 \%$ siswa sangat mampu dalam perkembangannya. Dengan persentase yaitu antara $75,01 \%-100 \%$ artinya media kartu kata sangat valid (dapat digunakan tanpa revisi). Dari penilaian tersebut dapat disimpulkan bahwa media kartu kata terkait dengan keberhasilan siswa pada aspek perkembangan bahasa, siswa mampu dalam perkembangannya sehingga dapat digunakan untuk pembelajaran membaca permulaan di kelas 1 SD.

\section{Uji Coba Lapangan (Kelompok Besar)}

Setelah dilakukan revisi dari produk awal berdasarkan uji coba kelompok kecil terkait dengan kemudahan, kesenangan dan keamanan siswa dalam pembelajaran menggunakan media kartu kata maka dilanjutkan ke tahap uji lapangan (kelompok besar) sebanyak 20 siswa. Satu orang guru kelas 1 melakukan observasi kepada siswa yang sedang mengikuti pembelajaran menggunakan media kartu kata terkait dengan kemudahan siswa dalam melakukan pembelajaran. Hasil uji coba lapangan terhadap produk 
awal media kartu kata pada aspek keterampilan membaca permulaan pada siswa, diperoleh dari observasi tentang kemudahan, kesenangan, dan keamanan siswa dalam mengaplikasikan kegiatan pembelajaran menggunakan media kartu kata serta keberhasilan siswa pada aspek keterampilan membaca permulaan yang dilakukan oleh satu orang guru kelas 1.

Berdasarkan hasil analisis uji coba lapangan terhadap 20 siswa kelas $1 \mathrm{SD}$, dengan kemudahan pembelajaran menggunakan media kartu kata diperoleh data hasil uji coba sebanyak 94\% siswa mudah menggunakan media kartu kata. Dengan demikian hasil klasifikasi persentase yaitu 75,01\% - $100 \%$ tergolong dalam klasifikasi sangat valid (dapat digunakan tanpa revisi). Dari penilaian tersebut dapat disimpulkan bahwa media kartu kata mudah dilakukan untuk pembelajaran pada siswa kelas $1 \mathrm{SD}$.

Hasil uji coba lapangan juga dilakukan terhadap 20 siswa yang diambil dari 4 kelompok, dan tiaptiap kelompok terdiri dari 5 siswa. Pengisian data pada siswa dilakukan oleh satu orang guru kelas 1 dengan menanyakan secara langsung pada siswa tentang kesenangan siswa dalam pembelajaran menggunakan media kartu kata. Data hasil uji coba lapangan tentang penggunaan media kartu kata.

Berdasarkan hasil analisis uji coba lapangan terhadap 20 siswa kelas 1 SD terkait dengan kesenangan siswa pada media kartu kata diperoleh data hasil uji coba sebanyak 94\% siswa senang melakukan pembelajaran menggunakan media kartu kata. Dengan demikian hasil klasifikasi persentase yaitu antara $75,01 \%$ - 100\% tergolong dalam klasifikasi sangat layak (dapat digunakan tanpa revisi). Dari penilaian tersebut disimpulkan bahwa media kartu kata menyenangkan untuk digunakan untuk pembelajaran membaca permulaan pada siswa kelas $1 \mathrm{SD}$.

Hasil uji coba lapangan juga dilakukan terhadap 20 siswa yang diambil dari 4 kelompok, dan tiap-tiap kelompok terdiri dari 5 siswa. Pengisian data pada siswa dilakukan oleh satu orang guru kelas 1 dengan melakukan observasi pada siswa tentang keamanan siswa dalam menggunakan media kartu kata. Data hasil uji coba lapangan tentang keamanan siswa terhadap penggunaan media kartu kata terlampir.
Berdasarkan hasil analisis uji coba lapangan terhadap 20 siswa kelas 1 SD terkait dengan keamanan siswa pada media kartu kata diperoleh data hasil uji coba sebanyak $100 \%$ siswa aman melakukan pembelajaran menggunakan media kartu kata. Dengan demikian hasil klasifikasi persentase yaitu antara $75,01 \%$ - 100\% tergolong dalam klasifikasi sangat layak (dapat digunakan tanpa revisi). Dari penilaian tersebut dapat disimpulkan bahwa penggunaan media kartu kata aman digunakan untuk pembelajaran membaca permulaan pada siswa kelas $1 \mathrm{SD}$.

Hasil uji coba lapangan juga dilakukan terhadap 20 siswa yang diambil dari 4 kelompok, dan tiaptiap kelompok terdiri dari 5 siswa. Pengisian data pada siswa dilakukan oleh satu orang guru kelas 1 dengan melakukan observasi pada siswa terkait dengan keberhasilan siswa pada aspek keterampilan membaca permulaan pada saat pembelajaran menggunakan media kartu kata. Data hasil uji coba lapangan tentang keberhasilan pada aspek bahasa siswa dalam penggunaan media kartu kata.

Hasil pengolahan data hasil uji coba lapangan terkait dengan keberhasilan siswa pada aspek bahasa yaitu mencapai 97,18\% siswa sangat mampu dalam perkembangannya. Dengan persentase yaitu antara $75,01 \%$ - 100\% artinya media kartu kata sangat valid dan dapat digunakan tanpa revisi. Dari penilaian tersebut dapat disimpulkan bahwa media kartu kata terkait dengan keberhasilan siswa pada aspek perkembangan bahasa, siswa sangat mampu dalam perkembangannya sehingga dapat digunakan untuk pembelajaran membaca permulaan pada siswa kelas 1 di SD.

Berdasarkan data keseluruhan dari uji lapangan kelompok besar terhadap 20 siswa kelas 1 tersebut, dapat disimpulkan bahwa media kartu kata mudah, aman, dan menyenangkan serta siswa mampu dalam perkembangannya untuk pembelajaran membaca permulaan di kelas 1 SD. Sejalan dengan pemngembangan media kartu kata dengan model induktif kata bergambar (Patty, 2015). Dengan demikian maka kegiatan membaca merupakan kegiatan sangat diperlukan untuk meningkatkan diri. Oleh sebab itu, pembelajaran membaca di sekolah mempunyai peranan penting (Zuchdi \& Budiasih, 1997:49). 


\section{SIMPULAN DAN SARAN}

\section{Simpulan}

Pelaksanaan pembelajaran Pengembangan Media Kartu Kata untuk Melatih Keterampilan Membaca Permulaan pada Siswa Kelas 1 SD, berhasil dikembangkan dan mampu melatih keterampilan membaca permulaan. Setelah melalui beberapa tahapan, mulai dari tinjauan beberapa ahli pembelajaran, uji kelompok kecil dan uji lapangan (kelompok besar).

Berdasarkan hasil analisis data uji lapangan kelompok besar, diperoleh persentase yaitu (1) $94 \%$ siswa mudah menggunakan media kartu kata; (2) 94\% siswa senang menggunakan media kartu kata; (3) $100 \%$ siswa aman menggunakan media kartu kata; (4) \% siswa mampu dalam perkembangannya terkait dengan keberhasilan siswa pada aspek bahasa, maka dapat disimpulkan bahwa media kartu kata dapat digunakan sebagai salah satu alternatif pembelajaran yang mudah untuk dilakukan, menyenangkan dan tidak membahayakan siswa dalam kegiatan pembelajaran Bahasa Indonesia untuk melatih keterampilan membaca permulaan pada siswa kelas 1 .

\section{Saran}

Setelah mengetahui hasil dan kesimpulan selama penelitian berlangsung di kelas $1 \mathrm{SD}$, maka peneliti dapat memberikan beberapa saran yang membangun supaya dapat dijadikan bahwa pertimbangan dalam upaya memperbaiki dan meningkatkan kualitas kegiatan pembelajaran selanjutnya. Beberapa saran yang dapat dijadikan sebagai bahan pertimbangan sebagai berikut ini. Pertama, saran pemanfaatan. Produk pengembangan ini adalah media kartu kata yang dapat digunakan sebagai rujukan oleh pendidik sekolah dasar. Dalam memanfaatkannya perlu mempertimbangkan situasi, usia, dan tingkat perkembangan siswa. Produk yang ditujukan untuk siswa usia 6-7 tahun di SD. Namun produk ini juga dapat digunakan di sekolah lain. Kedua, saran diseminasi. Dalam penyebarluasan produk media kartu kata ke sasaran yang lebih luas, peneliti memberikan saran sebagai berikut: (a) Sebelum disebarluaskan sebaiknya produk ini dievaluasi kembali dan disesuaikan dengan situasi dan kondisi sasaran yang dituju, (b) Sebelum disebarluaskan sebaiknya disosialisasikan kepada sekolah-sekolah lainnya.
Ketiga, saran pengembangan lebih lanjut. Dalam pengembangan lebih lanjut disarankan antara lain: (a) Bagi subjek penelitian (Siswa) dapat dilakukan pada subjek yang lebih luas, dengan memperhatikan usia yang menjadi subjek pelaku, (b) Bagi guru atau pendidik dapat memiliki pilihan, memberikan wawasan dan pengetahuan baru tentang pembelajaran terkait dengan keberhasilan siswa dalam melatih aspek bahasa siswa usia 6-7 tahun, (c) Bagi sekolah dapat mengembangkan inovasi, kreativitas dan profesionalisme guru melalui pengembangan media, sehingga akan mengembangkan dan meningkatkan mutu pendidikan di sekolah tersebut, (d) Bagi peneliti selanjutnya yang ingin memperdalam media kartu kata disarankan agar memperhatikan tingkat perkembangan siswa serta mengembangkan lebih luas lagi dalam bidang pengembangan lainnya misalnya pengembangan aspek bahasa dalam kegiatan menulis, mendengarkan dan bercerita.

\section{DAFTAR RUJUKAN}

Basuki, I.A. 2011. Profil Pembelajaran Membaca Pemahaman di Sekolah Dasar. Jurnal Sekolah Dasar. Th. 20 No. 2 November 2011.

Depdiknas.2006. Standar Isi Satuan Pendidikan sekolah Dasar dan Menengah. Jakarta: KKPS Kabupaten Malang.

Hartati, T. 2016. Multimedia Dalam Pengembangan Literasi di Sekolah Dasar Terpencil Jawa Barat. Jurnal Sekolah Dasar. 25(1):31-45

Irtadji, Tutut, C., \& Rumidjan. 2014. Model Pelatihan Pembelajaran Kreatif Bagi Guru Sekolah Dasar. Jurnal Sekolah Dasar. 23(2): 65-78

Patty, R. 2015. Pengembangan Model Induktif Kata Bergambar pada Pembelajaran Menulis Permulaan di Kelas II SD. Jurnal Sekolah Dasar. 26(2): 34-45.

PISA. 2003. Measuring Student Knowledge and Skills: A New Framework for Assessment. Paris: OECD.

Sanjaya, W. 2009. Strategi Pembelajaran Berorientasi Standar Proses Pendidikan. Jakarta: Kencana Prenada Media Group.

Santosa. 2007. Materi dan Pembelajaran Bahasa Indonesia SD. Jakarta: Universitas Terbuka.

Setyoningsih, Y. 2008. Penggunaan Alat Permainan Kartu Kata Bergambar untuk Meningkatkan Keterampilan Membaca Permulaan Siswa Kelas 1 SDN Trewung Kecamatan Grati 
Kabupaten Pasuruan. Skripsi tidak diterbitkan. Malang: FIP Universitas Negeri Malang.

Sukmadinata, N. S. 2013. Metode Penelitian Pendidikan. Bandung: PT. Remaja Rosdakarya.

Sukartiningsih, W. 2010. Pengembangan Media CD Interaktif untuk Membaca di Kelas 1 Sekolah Dasar. Jurnal Sekolah Dasar. 19(2): 78-89

Tarigan. 1983. Menulis Sebagai Suatu Keterampilan Berbahasa. Bandung: Angkasa.
Universitas Negeri Malang. 2010. Pedoman Penulisan Karya Ilmiah Edisi Lima. Malang: Universitas Negeri Malang.

Zuchdi \& Budiasih. 1997. Pendidikan Bahasa dan Sastra Indonesia di Kelas Rendah. Jakarta: Departemen Pendidikan dan Kebudayaan Direktorat jenderal Pendidikan Tinggi dan Proyek Pengembangan Guru Sekolah Dasar. 